\title{
The Effect of Cooperative Learning and Thinking Ability toward Writing Skill of Exposition Paragraph
}

\author{
${ }^{1}$ Etik, ${ }^{2}$ Ninuk Lustyantie, ${ }^{3}$ Emzir \\ ${ }^{1}$ Doctoral Program in Faculty Language Education of Jakarta State University, ${ }^{2}$ Lecturer of Jakarta state \\ University, ${ }^{3}$ Lecturer of Jakarta State University
}

\begin{tabular}{|c|c|}
\hline ARTICLE INFO & ABSTRACT \\
\hline $\begin{array}{l}\text { Article history: } \\
\text { Received Jan 29, } 2020 \\
\text { Revised April 17, } 2020 \\
\text { Accepted Jun 19, } 2020\end{array}$ & \multirow{4}{*}{$\begin{array}{l}\text { The purpose of this study is to investigate the effect of Numbered } \\
\text { Head Together (NHT) type and Cooperative Script (CS) type of } \\
\text { cooperative learning (creative and critical thinking ability) toward the } \\
\text { skill of writing exposition paragraph to the second-semester students } \\
\text { of Indonesian Language and Literature Education Study Program, } \\
\text { University of Cokroaminoto. This study employed the quantitative } \\
\text { research approach of the experimental method with a } 2 \times 2 \text { factorial } \\
\text { design. The test results of the exposition paragraph writing and the } \\
\text { thinking ability were analyzed by using a two-way ANOVA design } \\
\text { with } 0.05 \text { of the significance level. The sample of this study used the } \\
\text { multi-stage random sampling technique for } 68 \text { students. The result of } \\
\text { this research found that students could have high scores in writing } \\
\text { exposition paragraphs if teachers employed the cooperative learning } \\
\text { model of NHT type so that they could possess the critical thinking } \\
\text { ability. The students who had high critical thinking skills got better } \\
\text { scores in writing. Conversely, the students who had low critical } \\
\text { thinking skills got lower scores in writing. }\end{array}$} \\
\hline $\begin{array}{l}\text { Keywords: } \\
\text { Writing Exposition Paragraph } \\
\text { Cooperative Models (NHT and } \\
\text { CS) type } \\
\text { Critical Thinking Ability } \\
\text { Creativity }\end{array}$ & \\
\hline $\begin{array}{l}\text { Clonflict of Interest: } \\
\text { None }\end{array}$ & \\
\hline Funding: & \\
\hline \multicolumn{2}{|l|}{ None } \\
\hline \multicolumn{2}{|c|}{$\begin{array}{l}\text { Corresponding Author: Etik, Doctoral Program in Faculty Language Education of Jakarta State University, } \\
\text { etik_pb15s3@mahasiswa.unj.ac.id }\end{array}$} \\
\hline & $\begin{array}{r}\text { Copyright@Association of Language Teachers in Southeast Asia. } \\
\text { All rights reserved }\end{array}$ \\
\hline
\end{tabular}

\section{Introduction}

One of those four language skills that must be thought by the teacher is writing skills. It has always an important place in most English language courses. One of the reasons is that more people need to learn writing for academic purposes. To write well people must have good capabilities in writing. Moreover, people who want to write an essay or story must know the steps in writing.

Enre (1988:13) defines that writing is a process of thinking systematically. There is a correlation between thinking and writing because when we are writing something we must think of what we want to write. Brown (2001) mentions "Writing is indeed a thinking process" (p. 336), that is, writers produce a final written product after going through the thinking process.

Based on the observation of the students of Cokroaminoto Palopo University, the researcher found that the students have some difficulties to choose words for arranging sentences because they were not creative and had critical thinking in the writing class. As a result, they need some activities to stimulate their creativity and critical thinking by using the cooperative method namely, Numbered Head Together (NHT).

Kagan (1994: 20) who develops Numbered Head Together technique describes that in this technique the teacher gives numbers to each student and gives questions to every student based on their numbers. It is one of the ways to ensure more equitable response opportunities by stopping to call on students who raise their hands. Besides that, it can give the same opportunities for each student to actively engage in the 
teaching and learning processes. Maman and Rajab (2016) find that the implementation of the cooperative learning model of (NHT) on students of SMPN 2 Maros can improve the students' ability in reading comprehension, Yudi Hari Rayanto (2017) states that Numbered Head Together technique can improve the students' reading comprehension skill in narrative texts at eight graders of SMP Negeri 1 Rejoso. Therefore, to solve the problem, the researcher used cooperative learning. According to Slavin (1995: 2), cooperative learning refers to a variety of teaching methods in which students work in small groups to help one another learn academically, to discuss and argue with each other, to assess each other's current knowledge and fill in gaps in each other's understanding. Besides that, Kagan (2009) defines cooperative learning as an organized group learning activity so that learning is dependent on the socially structured exchange of information between learners in groups in which each learner is accountable for his or her learning and motivated to increase the learning of others. In cooperative learning, heterogeneous grouping, positive interdependence, and individual accountability are emphasized. Within a cooperative learning group, students work together and are formally accountable for their own and one another's learning. The study is designed to improve the student's reading comprehension in narrative texts through one of the kinds of cooperative learning namely, numbered head together.

From the explanation above, the researcher is interested in conducting the research entitled "the effect of cooperative learning and thinking ability toward writing skill of exposition paragraph" to find out the effect of cooperative learning and thinking ability toward the skill of writing exposition paragraph at second-semester students of Indonesian Language and Literature Education Study Program of Cokrominoto University Palopo.

\section{Review of Literature}

Writing is one of the important skills that language learners need to learn as an essential component not only for their academic practice but also later in their professional life. Writing can be defined in various ways. There are some definitions of writing proposed by experts. Byrne (1997:1) says that on one level, writing can be said to be the act of forming symbols; making marks on a flat surface of some kind. Graphic symbols here include letters or combinations of letters that relate to the sound people make when they speak. The symbols have to be arranged, according to certain conventions, to form words, sentences, and/or paragraphs. However, writing is more than the production of graphic symbols. He also states that writing involves the encoding of a message of some kind; that is translating thoughts into language. Besides, Hadfield (1990) says that writing is an artificial activity in a way that speech is not. While Enre (1988:13) defines that writing is a process of thinking systematically so that what is being written can be easily understood. Harmer (2004: 86) states that writing is a process that what we write is often heavily influenced by the constraints of genres, and then these elements have to be present in learning activities. It means writing cannot be separated from genres especially in teaching-learning activities of writing. In this case, writing activities can be present in the classroom.

From the definitions of writing above, it can be concluded that writing is an activity of thinking after which it is expressed into graphic symbols, in a communicative written language. In expressing the thought into a written language, feeling plays an important role as well, so that the products will be easily understood and enjoyed by readers. To do so, of course, it needs a good and interesting language. In other words, writing is closely related to the thought, feeling, and ability in using a language. In this case, a communicative language is completely needed.

As Coelho (1991) states, cooperative learning is an approach to education based on the philosophy that education should be learner-centered and learner-directed; that learners can be teachers; and that teachers are guides and facilitators rather than the source of all knowledge and direction.

Slavin (1983) states that cooperative learning helps the students interact with their peers in contributing to gains in academic achievement. In cooperative learning, the students can teach one another to accomplish the group goal. The students work together to learn and to be responsible for their fellow students' learning as well as their own. Further, Slavin (1995) asserts "Cooperative learning methods are practical classroom techniques teachers can use every day to help students learn any objectives, from basic skills to complex problem-solving." Similarly, Egbulefu Christian Alabekee (2015) cooperative learning is both an enjoyable and effective teaching strategy and result in significantly higher learning gains and positive learning experience compared to traditional instruction. It provides students' opportunity to interact with their classmates and such interaction develops in them feelings of cooperation and care for others. It also improves students' ability in problem-solving. Besides that, students also learn how to interrupt other students politely, how to give their opinion, and how to praise other students. 
From the definitions of cooperative learning, the researcher concludes that cooperative learning is a method in teaching and learning in which the classroom is organized so that students work together in small cooperative teams with clearly defined roles. Chua Yan Piaw (2004: 18) mentions there are some indicators of critical and creative thinking, are :

\section{- The indicators of critical thinking are:}

1) Search for "meaningful”, "clear", "consistent”, logical, "precise”, "accurate”, "Justify”, "relevant" and "true" in everything."

2) Avoid making mistakes.

3) Follow some rules and criteria in the thinking process.

4) Think more precisely and critically in the process of thinking.

5) Avoid emotional reasoning.

6) Evaluate the degree of truth or falsity of things before making a decision.

7) Like to Evaluate the logic, validity, and relevance of data.

8) In evaluate of ideals, believe that there is only one way of being right.

9) Evaluate carefully before any action taken.

10) Distinguish between observation and inference.

11) Try to stick to the main points.

12) Respect clarity and precision.

13) Like to ask questions: search for the degree of truth.

14) The ability to ask questions, defining problems, examining evidence analyzing assumptions, and biases.

15) Always look for the best way to solve a problem.

16) Good at reasoning.

17) Do not believe in illusion or magic.

18) Believe that things can't change overnight.

19) Argumentative and like to criticize facts.

20) High judgment skills

21) Like to discuss political issues.

22) Establish clear criteria for evaluating ideas, issues, or positions.

Based on the explanation above, it can be concluded that critical thinking is the ability to think logically and accurately and how to find the solution, solve the problem, understand the situation of the problem, analyze the problem, and evaluate decisions or solutions.

\section{The indicators of creative thinking are:}

1) Generate unique ideas that others cannot think of.

2) Shift from the normal perspective to take a different point of view.

3) View things in other than normal ways.

4) Imaginative and confident in one's ideal.

5) Aesthetic orientation.

6) Understand the beauty of art.

7) Potential for generating further ideas and changes.

8) Able to produce an abundance of ideas in a fixed time.

9) The tendency to view a problem instantly from a variety of perspectives.

10) Do not get stuck by assuming the rules which do not apply to a problem.

11) Likely to bend the rules.

12) Need some breathing space for incubation in the middle of the creative process.

13) Able to resist the tendency to leap to a conclusion prematurely.

14) Able to keep open and to make the mental leap beyond the limit freely.

15) Able to capture the essence of the given information, to produce an imaginative, abstract but appropriate title.

16) Able to communicate clearly and powerfully through storytelling.

17) Like to fantasize (fantasy provides an almost inexhaustible supply of analogies that are useful in stating and solving a problem creatively).

18) Like daydreaming and are emotional 
19) The tendency to combine two elements into one.

20) The tendency to present and recognize ideas or objects in unusual visual order than a static, upright, straight to the view, the usual and common perspective given by the majority of people).

21) Able to visualize beyond the exterior and pay attention to the internal, dynamic working of things.

22) Able to extend and break the boundaries of the problem (breaking the creative thinking blockage).

23) Good sense of humor (humor is basically creative because it involves the unusual enterprise).

Based on the explanation above, it can be concluded that creative thinking is the ability to produce original ideas, and also generates unique ideas by making something new.

\section{- Hypothesis}

Based on the review above, the researcher proposes the hypothesis formula as follows:

$\mathrm{H}_{0}=$ There is no significant effect of cooperative learning and thinking ability toward writing skills of exposition paragraphs.

$\mathrm{H}_{1}=$ There is a significant effect of cooperative learning and thinking ability toward writing skills of exposition paragraphs.

\section{Research Method}

The research applies quantitative research. The population of the research is the general students of Cokroaminoto Palopo University. The sample took 68 students. For instruments, the researcher used the writing test of an exposition paragraph and the test of thinking ability from which have been made based on the related theory. The procedures to collect the data are: 1) in the pretest, the researcher gave a writing test to the students to know the students' abilities before the treatment. 2) in the treatment, the researcher gave some topics to discuss, then each group shared the discussions. 3) in the posttest, the researcher gave a writing test of an expository paragraph. In this research, the techniques for analyzing the data were:

a. Scoring correct answers to the test.

$$
\text { Score }=\frac{\text { guide scorrect answer }}{\text { totalnumber }} \times 100
$$

(Depdikbud,1993: 26)

b. Classifying the students' score into some classification below :
a. Excellent : $9.6-10$ classified as excellent
b. Very good : $8.6-9.5$ classified as very good
c. Good : $7.6-8.5$ classified as good
d. Fairly good : $6.6-7.5$ classified as fairly good
e. Fairly : $5.6-6.5$ classified as fairly
f. Fairly poor : $\quad 3.6-5.5$ classified as fairly poor
g. Poor : $0-3.5$ classified as poor

(Brown, 2004)

\section{Result}

Based on the research method, this research used a two-way ANOVA. In this step before testing the hypothesis, first, need to Test of normality and test homogeneity.

\section{- Test of normality}

Table 4.1 the result of the Test of normality writing skill of paragraph exposition.

\begin{tabular}{clll}
\hline $\begin{array}{c}\text { Group } \\
\text { Sample }\end{array}$ & \multicolumn{1}{c}{ Hypothesis } & Result of Testing & \multicolumn{1}{c}{ Conclusions } \\
\hline $\mathrm{A}_{1}$ & $\begin{array}{l}\text { H0: The normal } \\
\text { population } \\
\text { distribution, if the } \\
\text { probability }>0.05,\end{array}$ & $\begin{array}{l}\text { Test Statistic of } 0.126, \\
\text { this figure equals the } \\
\text { result on the line } \\
\text { Asymp. A Sig. (2- } \\
\text { tailed) of } 0.113 \text { or can }\end{array}$ & $\begin{array}{l}\text { The group data that } \\
\text { study with NHT } \\
\text { was the normal } \\
\end{array}$ \\
\hline
\end{tabular}




\begin{tabular}{|c|c|c|c|}
\hline & $\begin{array}{l}\text { H0 acceptable. } \\
\text { H1: Abnormal } \\
\text { population } \\
\text { distribution, if } \\
\text { probability } \leq 0.05 \mathrm{H} 0 \\
\text { rejected. }\end{array}$ & $\begin{array}{l}\text { be written as a } \\
\text { probability value }(\mathrm{P}- \\
\text { value })=0.113>0.05 \\
\text { or } \mathrm{H} 0 \text { accepted. }\end{array}$ & \\
\hline $\mathrm{A}_{2}$ & $\begin{array}{l}\text { H0: The normal } \\
\text { population } \\
\text { distribution, if the } \\
\text { probability }>0.05 \text {, } \\
\text { H0 acceptable. } \\
\text { H1: Abnormal } \\
\text { population } \\
\text { distribution, if } \\
\text { probability } \leq 0.05 \mathrm{H} 0 \\
\text { rejected. }\end{array}$ & $\begin{array}{l}\text { Test Statistic of } 0.143 \text {, } \\
\text { this figure equals the } \\
\text { result on the line } \\
\text { Asymp. A Sig. ( } 2- \\
\text { tailed) of } 0.111 \text { or can } \\
\text { be written as a } \\
\text { probability value (P- } \\
\text { value) }=0.111>0.05 \\
\text { or H0 accepted. }\end{array}$ & $\begin{array}{l}\text { The group data that } \\
\text { study with CS are } \\
\text { the normal } \\
\text { distribution. }\end{array}$ \\
\hline $\mathrm{B}_{1}$ & $\begin{array}{l}\text { H0: The normal } \\
\text { population } \\
\text { distribution, if the } \\
\text { probability }>0.05, \\
\text { H0 acceptable. } \\
\text { H1: Abnormal } \\
\text { population } \\
\text { distribution, if } \\
\text { probability } \leq 0.05 \mathrm{H} 0 \\
\text { rejected. }\end{array}$ & $\begin{array}{l}\text { Test Statistic of } 0.183 \text {, } \\
\text { this figure equals the } \\
\text { result on the line } \\
\text { Asymp. A Sig. ( } 2- \\
\text { tailed) of } 0.203 \text { or can } \\
\text { be written as a } \\
\text { probability value (P- } \\
\text { value) }=0.203>0.05 \\
\text { or } \mathrm{H} 0 \text { accepted. }\end{array}$ & $\begin{array}{l}\text { The Group Data } \\
\text { that has critical } \\
\text { thinking } \\
\text { capabilities with the } \\
\text { normal distribution. }\end{array}$ \\
\hline $\mathrm{B}_{2}$ & $\begin{array}{l}\text { H0: The normal } \\
\text { population } \\
\text { distribution, if the } \\
\text { probability }>0.05, \\
\text { H0 acceptable. } \\
\text { H1: Abnormal } \\
\text { population } \\
\text { distribution, if } \\
\text { probability } \leq 0.05 \mathrm{H} 0 \\
\text { rejected. }\end{array}$ & $\begin{array}{l}\text { Test Statistic of } 0.200 \text {, } \\
\text { this figure equals the } \\
\text { result on the line } \\
\text { Asymp. A Sig. ( } 2- \\
\text { tailed) of } 0.054 \text { or can } \\
\text { be written as a } \\
\text { probability value (P- } \\
\text { value) }=0.054>0.05 \\
\text { or H0 accepted. }\end{array}$ & $\begin{array}{l}\text { The Group Dats } \\
\text { that has creative } \\
\text { thinking } \\
\text { capabilities with the } \\
\text { normal distribution. }\end{array}$ \\
\hline $\mathrm{A}_{1} \mathrm{~B}_{1}$ & $\begin{array}{l}\text { H0: The normal } \\
\text { population } \\
\text { distribution, if the } \\
\text { probability }>0.05 \text {, } \\
\text { H0 acceptable. } \\
\text { H1: Abnormal } \\
\text { population } \\
\text { distribution, if } \\
\text { probability } \leq 0.05 \mathrm{H} 0 \\
\text { rejected. }\end{array}$ & $\begin{array}{l}\text { Test Statistic of } 0.157 \text {, } \\
\text { this figure equals the } \\
\text { result on the line } \\
\text { Asymp. A Sig. ( } 2- \\
\text { tailed) of } 0.484 \text { or can } \\
\text { be written as a } \\
\text { probability value (P- } \\
\text { value) }=0.484>0.05 \\
\text { or H0 accepted. }\end{array}$ & $\begin{array}{l}\text { The student group } \\
\text { data who study with } \\
\text { NHT learning } \\
\text { models on students } \\
\text { who have critical } \\
\text { thinking skills with } \\
\text { the normal } \\
\text { distribution. }\end{array}$ \\
\hline $\mathrm{A}_{1} \mathrm{~B}_{2}$ & $\begin{array}{l}\text { H0: The normal } \\
\text { population } \\
\text { distribution, if the } \\
\text { probability }>0.05 \text {, } \\
\text { H0 acceptable. } \\
\text { H1: Abnormal } \\
\text { population }\end{array}$ & $\begin{array}{l}\text { Test Statistic of } 0.121 \text {, } \\
\text { this figure equals the } \\
\text { result on the line } \\
\text { Asymp. A Sig. ( } 2 \text { - } \\
\text { tailed) of } 0.570 \text { or can } \\
\text { be written as a } \\
\text { probability value (P- }\end{array}$ & $\begin{array}{l}\text { The Student group } \\
\text { Data that has } \\
\text { creative thinking } \\
\text { skills with the } \\
\text { normal distribution } \\
\text { NHT model. }\end{array}$ \\
\hline
\end{tabular}




\begin{tabular}{|c|c|c|c|}
\hline & $\begin{array}{l}\text { distribution, if } \\
\text { probability } \leq 0.05 \mathrm{H} 0 \\
\text { rejected. }\end{array}$ & $\begin{array}{l}\text { value) }=0.570>0.05 \\
\text { or H0 accepted. }\end{array}$ & \\
\hline $\mathrm{A}_{2} \mathrm{~B}_{1}$ & $\begin{array}{l}\text { H0: The normal } \\
\text { population } \\
\text { distribution, if the } \\
\text { probability }>0.05 \text {, } \\
\text { H0 acceptable. } \\
\text { H1: Abnormal } \\
\text { population } \\
\text { distribution, if } \\
\text { probability } \leq 0.05 \mathrm{H} 0 \\
\text { rejected. }\end{array}$ & $\begin{array}{l}\text { Test Statistic of } 0.178 \text {, } \\
\text { this figure equals the } \\
\text { result on the line } \\
\text { Asymp. A Sig. ( } 2- \\
\text { tailed) of } 0.657 \text { or can } \\
\text { be written as a } \\
\text { probability value (P- } \\
\text { value) }=0.657>0.05 \\
\text { or } \mathrm{H} 0 \text { accepted. }\end{array}$ & $\begin{array}{l}\text { The student group } \\
\text { data who study with } \\
\text { CS models on } \\
\text { students who have } \\
\text { critical thinking } \\
\text { skills with the } \\
\text { normal distribution. }\end{array}$ \\
\hline $\mathrm{A}_{2} \mathrm{~B}_{2}$ & $\begin{array}{l}\text { H0: The normal } \\
\text { population } \\
\text { distribution, if the } \\
\text { probability }>0.05 \text {, } \\
\text { H0 acceptable. } \\
\text { H1: Abnormal } \\
\text { population } \\
\text { distribution, if } \\
\text { probability } \leq 0.05 \mathrm{H} 0 \\
\text { rejected. }\end{array}$ & $\begin{array}{l}\text { Test Statistic of } 0.173 \text {, } \\
\text { this figure equals the } \\
\text { result on the line } \\
\text { Asymp. A Sig. ( } 2- \\
\text { tailed) of } 0.286 \text { or can } \\
\text { be written as a } \\
\text { probability value (P- } \\
\text { value) }=0.286>0.05 \\
\text { or } \mathrm{H} 0 \text { accepted. }\end{array}$ & $\begin{array}{l}\text { The student group } \\
\text { data who study with } \\
\text { CS learning models } \\
\text { in students who } \\
\text { have creative } \\
\text { thinking skills with } \\
\text { the normal } \\
\text { distribution. }\end{array}$ \\
\hline
\end{tabular}

- Test Homogeneity.

Table 4.2. the result of Test Homogeneity Writing skill of paragraph exposition.

\begin{tabular}{cccc}
\hline Levene Statistic & df1 & df2 & Sig. \\
\hline .967 & 3 & 64 & .414 \\
\hline
\end{tabular}

The table above shows that test of homogeneity of variance has got $\mathrm{F}=0,967 ; \mathrm{db} 1=3 ; \mathrm{db} 2=$ 64 , and p-value $=0,414>0,05$ or $\mathrm{H}_{0}$ accepted. It can be concluded that the analysis of testing ANAVA two-way can be continuous to the next hypothesis of testing.

\section{- Hypothesis Testing}

1. The difference in writing the exposition paragraphs between the student groups learning by using cooperative learning model type Numbered Head Together (NHT) and Cooperative Script type (CS).

$\mathrm{H}_{0}: \mu \mathrm{A}_{1} \leq \mu \mathrm{A}_{2}$

$\mathrm{H}_{1}: \mu \mathrm{A}_{1}>\mu \mathrm{A}_{2}$

From the data analysis, it shows that $F_{\text {calculation }}(A)=235,019$ and $p$-value $=0,000<0,05$, or $\mathrm{H}_{0}$ is rejected. It can be concluded that there is a difference in the score of writing exposition paragraphs between the students who studied with the cooperative learning type of Numbered Head Together (NHT) and Cooperative Script (CS). The calculation result, as well as the average value of the skills of writing the exposition of students learning by using the model of cooperative learning type NHT (A1), is 87.09. Meanwhile, the average value of the skills of writing a paragraph of Indonesian exposition of students studying with the cooperative learning model of cooperative script type (A2) is 82.21. Thus, the students' skills in writing the exposition paragraphs of the Indonesian language who studied with the cooperative learning model of NHT type are better than the group of students who studied by using the cooperative learning model of the Cooperative Script type. The explanation above can be concluded that the hypothesis stating there is a difference in the skills to write a paragraph of the Indonesian exposition 
between the student groups who learn by using the cooperative learning model of Numbered Head Together (NHT) type and Cooperative Script (CS) type is accepted and tested significantly.

2. The difference in the skills of writing exposition paragraphs between the student group that has critical thinking skills and students who have creative thinking skills

$\mathrm{H}_{0}: \mu \mathrm{B}_{1} \leq \mu \mathrm{B}_{1}$

$\mathrm{H}_{1}: \mu \mathrm{B}_{1}>\mu \mathrm{B}_{2}$

The analysis result of two-lane variance indicates that fcalculation $(\mathrm{B})=57.348$ with $\mathrm{P}$-value $=$ $0.000<0.05$, or H0 was rejected. This means there is an average difference in writing skills of the exposition between the students who can think critically and students who have creative thinking skills. The calculation result of the average value of the skills of writing the Indonesian exposition paragraphs on the group of students who has the critical thinking ability is 85.85 . While the average writing skills of an Indonesian exposition paragraph on students who have the creative thinking ability is 83.44 . Thus, it is concluded that the skill of writing a paragraph of the Indonesian exposition in the student group that can think critically better than the group of students who has creative thinking skills.

The explanation above can be concluded that the hypothesis stating there is a difference in the skills of writing paragraphs of the Indonesian exposition between the student groups who have the ability to think critically with students who have creative thinking skills is accepted and tested significantly.

3. The influence of interaction between the cooperative learning model of the Numbered Head Together (NHT) type and Cooperative Script (CS) type on the ability of critical and creative thinking on the skills of writing a paragraph of the Indonesian Exposition.

$\mathrm{H}_{0}: \mu \mathrm{A} \times \mathrm{B}=0$

$\mathrm{H}_{1}$ : Int. $\mathrm{Ax} \mathrm{B} \neq 0$

The analysis result of two-lane variance indicates that $\mathrm{F}_{\text {calculation }}(\mathrm{AB})=85.288$ with $\mathrm{P}$-value $=$ $0.000<0.05$, or $\mathrm{H} 0$ is rejected. This means there is a very significant influence of interaction between factor A (learning model) and factor B (thinking ability) towards the students' skills of writing exposition paragraphs. From the analysis, the large influences of the variable model of learning are the ability to think, the interaction between the learning model, and the ability to think about the skills of writing a paragraph of the Indonesian exposition of $85.50 \%$. The influence of interactions between learning models and the ability to think about writing skills of exposition paragraphs, in the image below is the interaction between the learning model and the thinking ability to write exposition paragraphs:

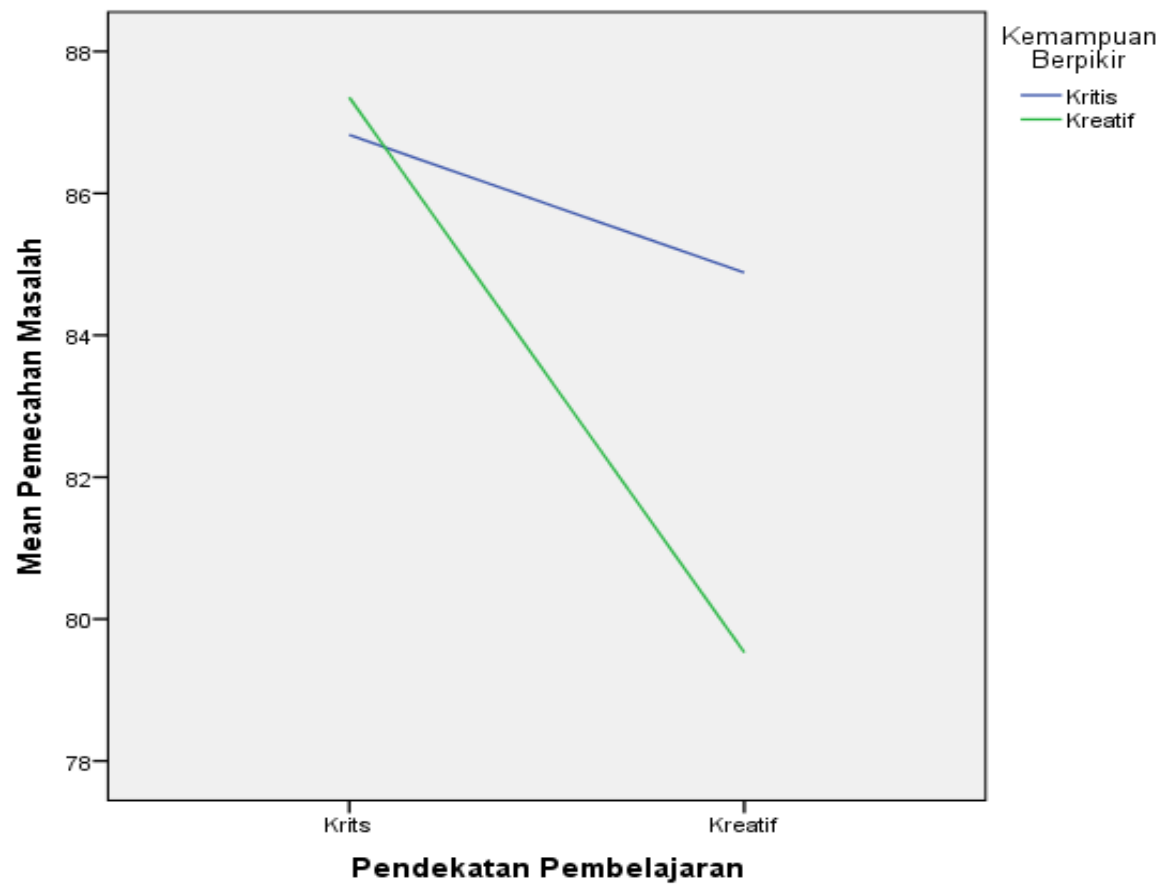

SALTeL Vol. 3, No. 2, 2020: $22-31$ 
From the picture above, it can be concluded that an interaction between the cooperative learning model of Numbered Head Together (NHT) type and Cooperative Script (CS) type on the ability of critical and creative thinking toward the skills of writing the exposition paragraphs is accepted and tested significantly.

4. The difference in the skills of writing exposition paragraphs in students who have critical thinking skills between students who learn by using the cooperative learning model of Numbered Head Together (NHT) type and Cooperative Script (CS) type.

$\mathrm{H}_{0}: \mathrm{A}_{1} \mathrm{~B}_{1} \leq \mathrm{A}_{2} \mathrm{~B}_{1}$
$\mathrm{H}_{1}: \mathrm{A}_{1} \mathrm{~B}_{1}>\mathrm{A}_{2} \mathrm{~B}_{1}$

Based on the results of the hypothesis test, it shows that $t_{\text {calculation }}=4,310, p$-value $=0,000 / 2=$ $0,000<0,05$ or $\mathrm{H}_{0}$ is rejected. Thus, there is a difference between writing skills of the student group exposition of the students who studied with the cooperative learning model of NHT type in students who have critical thinking skills and students who have creative thinking skills. The average value of the skills of writing an exposition paragraph of the Indonesian language of students studying with the cooperative learning model of NHT type who have the critical thinking ability (A1B1) is 86.82. While the average value of the skills of writing an exposition paragraph of the student group studying with the cooperative model of CS type who has the ability of critical thinking (A2B1) is 84.88. It was concluded that the results of the skills of writing the exposition paragraphs of students who study with the cooperative learning model of NHT in student groups who have the critical thinking ability (A1B1) better than a group of students learning with a CS type of the cooperative learning model that has the critical thinking ability (A2B1).

From the explanation above, it can be concluded the hypothesis stating there is a difference between the students' writings of exposition paragraphs who have critical thinking skills between students who learn using the cooperative learning model of Numbered Head Together (NHT) type and Cooperative Script (CS) type is accepted and tested significantly.

5. The difference in the writing skills of exposition paragraphs on students who have creative thinking skills between students who learn using the cooperative learning model of Numbered Head Together (NHT) type and Cooperative Script (CS) type.

$\mathrm{H}_{0}: \mathrm{A}_{1} \mathrm{~B}_{2} \leq \mathrm{A}_{2} \mathrm{~B}_{2}$
$\mathrm{H}_{1}: \mathrm{A}_{1} \mathrm{~B}_{2}>\mathrm{A}_{2} \mathrm{~B}_{2}$

Based on the results of the hypothesis test, it shows that $t_{\text {calculation }}=17,370, p$-value $=0,000 / 2=$ $0,000<0,05$ or $\mathrm{H}_{0}$ is rejected. Thus, there is a difference between the writing skills of the exposition paragraphs in the student group that has creative thinking skills between students who learned using the cooperative learning model of Numbered Head Together (NHT) type and Cooperative Script (CS) type. The average value of the skills of writing the paragraph of the Student Exposition Group which has the ability of creative thinking studying with the cooperative learning model of NHT type (A1B2) is 87.35. While the average skill of writing exposition paragraphs of the Indonesian language of students who studied with the CS approach on students who have creative thinking skills (A1B2) is 79.53. Thus, it was concluded that the skill of writing exposition paragraphs of the Indonesian language on students who have creative thinking skills studying with the cooperative learning model of NHT type (A1B2) better than the student group studying with the cooperative learning model of CS type for students who have creative thinking skills (A1B2). The explanation above can be concluded that the hypothesis stating there is a difference in the skills of writing exposition paragraphs of the Indonesian language in a group of students who has the ability of creative thinking between students who studied by using the cooperative learning model of Numbered Head Together (NHT) type and Cooperative Script (CS) type is accepted and tested significantly.

6. The difference in students' exposition paragraph writings studying with the cooperative learning model of Numbered Head Together (NHT) type between students who have the ability to think critically and students who have the ability to think creatively.

$\mathrm{H}_{0}: \mathrm{A}_{1} \mathrm{~B}_{1} \leq \mathrm{A}_{1} \mathrm{~B}_{2}$

$\mathrm{H}_{1}: \mathrm{A}_{1} \mathrm{~B}_{1}>\mathrm{A}_{1} \mathrm{~B}_{2}$

Based on the results of the hypothesis test shown that $t_{\text {calculation }}=-1,175$, $p$-value $=0,244 / 2=$ $0,122>0,05$ or $\mathrm{H}_{1}$ accepted. Therefore, there is a difference between the students' writing skills of the 
exposition paragraphs who learned by using the cooperative learning model of Numbered Head Together (NHT) type between students who have critical thinking skills and students who have creative thinking skills. The average value of the students' skills of writing exposition paragraphs of the Indonesian language learning by using the cooperative learning model of Numbered Head Together (NHT) type who have the critical thinking ability (A1B1) is 84.88. While the average value of the students' skills of writing exposition paragraphs learning by using the cooperative learning model of Numbered Head Together (NHT) type who have creative thinking ability (A1B2) is 87.35.

From the explanation above, it can be concluded that the hypothesis stating there is a difference between students' skills of writing exposition paragraphs learning by using the cooperative learning model of Numbered Head Together (NHT) type between students who have critical thinking skills and students who have the ability of creative thinking is accepted.

7. The difference in students' exposition paragraph writings studying with the cooperative learning model of CS type between students who have critical thinking skills and students who have creative thinking skills.

$\mathrm{H}_{0}: \mathrm{A}_{2} \mathrm{~B}_{1} \leq \mathrm{A}_{2} \mathrm{~B}_{2}$
$\mathrm{H}_{1}: \mathrm{A}_{2} \mathrm{~B}_{1}>\mathrm{A}_{2} \mathrm{~B}_{2}$

Based on the results of the seventh hypothesis test, it shows that $t_{\text {calculation }}=11,885, \quad p$-value $=$ $0,000 / 2=0,000<0,05$ or $\mathrm{H}_{0}$ is rejected. Thus, there is a difference in the students' writing skills of the exposition paragraph who studied with the cooperative learning model of Cooperative Script (CS) between students who have critical thinking skills and students who have creative thinking skills. The average value of the writing skills of the exposition paragraphs of the student group who studied with the cooperative learning model of CS type in students who have the ability of critical thinking (A2B1) is 84.88. Meanwhile, the average value of the writing skills of the exposition paragraphs of the student group studying with the cooperative learning model of CS type in students who have creative thinking ability (A2B2) is 79.53. Thus, it was concluded that the results of writing paragraphs of the Indonesian language exposition of students who studied with the cooperative learning model of CS type in students who have the critical thinking ability (A2B1) better than A group of students studying with the cooperative learning model of CS type on students who have the creative thinking skills (A2B2). The explanation above can be concluded that the hypothesis stating there is a difference in the skills of writing the Indonesian exposition paragraphs of students who studied by using the cooperative learning model of Cooperative Script type (CS ) between students who have the critical thinking ability and students who have the creative thinking ability is accepted and tested significantly.

\section{Conclusion}

Based on the result of the discussion, The result shows that (1) the mean score of the students' test result taught by NHT technique $\left(\mathrm{A}_{1}\right)$ was 87.09 while the mean score of the students' test result taught by CS Technique $\left(\mathrm{A}_{2}\right)$ was 82.21; (2) The effect of learning approach variable, thinking skill, and the interaction between learning approaches and thinking skills toward writing skills in Indonesian exposition paragraph was $85.50 \%$; (3) The mean score of the student group who has the ability to think creatively studying with the NHT cooperative approach type $\left(\mathrm{A}_{1} \mathrm{~B}_{2}\right)$ was 87.35 ; $(4)$ The mean score of students who have the creative thinking ability studying with NHT technique $\left(\mathrm{A}_{1} \mathrm{~B}_{2}\right)$ was 87.35 , while the mean score of students who studied with CS technique $\left(\mathrm{A}_{1} \mathrm{~B}_{2}\right)$ was 79.53 ; (5) The mean score of the students' test result taught by using NHT technique $\left(A_{1}\right)$ was 87.09 while the mean score of students who have creative thinking ability was 87.35. The researcher concluded that there is the effect of cooperative learning and thinking ability toward writing skills of exposition paragraphs. It'd better be critical thinking than creative thinking. Because we can be creative if we can think critically. Chua Yan Piaw (2004: 18) mentions that to know the students can think creatively or critically, there are some indicators of being creative and critical thinking. If the students have the critical thinking, they will have many ideas to express their writing. They can generate unique ideas to make something new. 


\section{References}

Brown, H.D.2001. Teaching by Principles: An Interactive Approach to Language Pedagogy 1st. Ed London. Longman.

Brown, H. Douglas. (2004). Language assessment: principles and classroom practice white Plains. New York: Person Longman.

Byrne, D. 1997. Teaching Writing Skills. New York: Longman.

Christian Alabekee E., Amaele Samuel \& Osaat D. S. 2015. "Effect of cooperative learning strategy on students learning experience and achievements in mathematic. International Journal of Education Learning and Development. Published by the European Centre for Research Training and Development UK link: www.eajournals.org.

Coelho, E. (1991). Jigsaw (Revised ed.). Markham, Ontario: Pippin Publishing Ltd.

Depdikbud, Donn. 1993. Dirjen Pendidikan Tinggi, Proyek Pengembangan LPTK.

Enre, Fachruddin Ambo.(1988).Dasar-Dasar Kerampilan Menulis. Jakarta.

Hadfield, Charles. 1990. Writing Games. Harlow: Longman.

Harmer, J. 2004. How to Teach Writing. London: Longman.

Hari, Yudi R. (2017). "Using Numbered Head Together to Improve The Student's Reading Comprehension in Narrative Text”. Journal of Research \& Method in Education. 2320-7388. DOI: 10.9790/7388-070202107114.

Kagan, S. 2009. Cooperative Learning. San Clemente, CA: Kagan. P.20.

Kagan, Spencer. 1994. Cooperative Learning. San Clemente, CA: Kagan. P.20.

Kessler, C. (Ed.). (1992). Cooperative language learning: A teacher's resource book. Englewood Cliffs, NJ: Prentice Hall Regents.

Maman, M \& Aryani, A.R. (2016). "The Implementation of Cooperative Learning Model 'Number Heads Together (NHT)' in Improving the Students' Ability in Reading Comprehension”. International Journal of Evaluation and Research in Education (IJERE). 2252-8822.

Piaw Chua Yan. 2004. Creative and Critical Thinking Styles. Malaysia: University Putra Malaysia Press.

Slavin. 1983. Cooperative Learning. New York: Longman.

Slavin. 1995. Cooperative learning: Theory, research, and practice (2nd publication) 